\title{
Analysis of the Resistance-Breaking Ability of Different Beet necrotic yellow vein virus Isolates Loaded into a Single Polymyxa betae Population in Soil
}

\author{
Kathrin Bornemann and Mark Varrelmann
}

First and second authors: Institute of Sugar Beet Research, Holtenser Landstr. 77, D-37079 Goettingen, Germany. Accepted for publication 1 February 2011.

\begin{abstract}
Bornemann, K., and Varrelmann, M. 2011. Analysis of the resistancebreaking ability of different Beet necrotic yellow vein virus isolates loaded into a single Polymyxa betae population in soil. Phytopathology 101:718-724.

The genome of most Beet necrotic yellow vein virus (BNYVV) isolates is comprised of four RNAs. The ability of certain isolates to overcome Rzl-mediated resistance in sugar beet grown in the United States and Europe is associated with point mutations in the pathogenicity factor P25. When the virus is inoculated mechanically into sugar beet roots at high density, the ability depends on an alanine to valine substitution at P25 position 67. Increased aggressiveness is shown by BNYVV $\mathrm{P}$ type isolates, which carry an additional RNA species that encodes a second pathogenicity factor, P26. Direct comparison of aggressive isolates trans-
\end{abstract}

ABSTRACT mitted by the vector, Polymyxa betae, has been impossible due to varying population densities of the vector and other soilborne pathogens that interfere with BNYVV infection. Mechanical root inoculation and subsequent cultivation in soil that carried a virus-free $P$. betae population was used to load $P$. betae with three BNYVV isolates: a European A type isolate, an American A type isolate, and a P type isolate. Resistance tests demonstrated that changes in viral aggressiveness towards $R z 1$ cultivars were independent of the vector population. This method can be applied to the study of the synergism of BNYVV with other $P$. betae-transmitted viruses.

Additional keywords: Beet soilborne virus, Benyvirus, durable resistance, host adaptation, quasispecies, virus evolution.
Rhizomania is one of the most devastating diseases of sugar beet in most areas in which it is grown. However, it has been controlled satisfactorily since a major resistance gene, $R z 1$, was isolated by the Holly Sugar Company (California) (23). This gene has been introduced into most of the commercial varieties that are currently grown worldwide (4). Different accessions of wild beet (WB) have been identified that harbor additional sources of resistance, such as $R z 2$ and $R z 3(9,38,39,46)$. The major resistance genes, in combination with other minor genetic factors, provide a variable degree of quantitative resistance (4). Resistant plants show reduced accumulation of the virus in small rootlets, inhibition of the spread of the virus to the taproot, and a lack of rootlet proliferation and other rhizomania-associated symptoms $(14,39,44)$.

Economic sugar production depends strongly on the durability of rhizomania resistance traits because severe infection can result in a reduction in yield as high as $90 \%$ in susceptible beets (15). As a consequence, the reemergence of aggressive forms of the disease in the United States $(25,27,36)$ and Europe (33) is of increasing concern.

Beet necrotic yellow vein virus (BNYVV), a member of the genus Benyvirus, which is the causal agent of rhizomania, is a multipartite single-stranded, positive-sense RNA virus. Its genome consists of four or five RNA species. RNA 1 and 2 contain the coding sequences for essential house-keeping functions, which include RNA replication, movement, vector transmission, encapsidation, and suppression of RNA silencing $(8,17,31)$. P31, which is encoded by RNA 4, is also involved in the suppression of RNA silencing and transmission by the protozoan Polymyxa betae

Corresponding author: M. Varrelmann; E-mail address: varrelmann@ifz-goettingen.de

doi:10.1094/PHYTO-06-10-0157

(c) 2011 The American Phytopathological Society
(35), whereas RNA 3-encoded P25 and RNA 5-encoded P26 are viral pathogenicity factors. P25 is responsible for the development of the typical symptoms of rhizomania in sugar beet roots $(16,44)$. P26 is an additional pathogenicity protein that acts in a synergistic manner with P25 (42). Isolates that contain RNA 5 have been found mainly in Asia (30), in Europe in a small region near Pithiviers, France (P type) (19), and recently at four locations in the United Kingdom $(12,45)$. The French P type is transported more rapidly in sugar beet roots (14) and produces a higher BNYVV content in $R z 1$-greenhouse plants $(32,33)$ than types with four RNA species, and also it is able to produce severe symptoms of rhizomania in the field (unpublished observations).

The ability of BNYVV that contains only four RNA species to overcome plant resistance has been linked to specific mutations in the RNA 3-encoded P25 pathogenicity factor $(1,2,27)$. Nucleotides 199 to 210 of the P25 open reading frame (ORF), which encode a tetrad of amino acids (aa 67 to 70), exhibit a high degree of variability among isolates around the world, and these isolates have different abilities to overcome resistance $(17,24,37,41)$. Recently, Koenig et al. (18) have used BNYVV pseudorecombinants and reverse genetics to prove that the substitution of valine for alanine at aa 67 of P25 in a Swedish A type isolate with four RNAs is responsible for the elevated virus content in $R z l$ and $R z 1+R z 2$ plants following mechanical root inoculation.

To date, separation of BNYVV isolate aggressiveness and resistance-breaking abilities from other interfering soilborne factors has been impossible and also direct comparison of isolate aggressiveness in soil resistance tests. In soil samples that have the ability to overcome $R z l$ resistance, we have observed additional severe infestation with the plant pathogens Aphanomyces cochlioides, Fusarium oxysporum, and Rhizoctonia solani. These pathogens might increase the symptoms of rhizomania or benefit from root injuries due to $P$. betae and virus infection (32). However, the 
possible synergistic or antagonistic interactions between BNYVV and other soilborne viruses that infect sugar beet and are transmitted by $P$. betae, such as Beet soilborne virus (BSBV), Beet soilborne mosaic virus (BSBMV), Beet oak-leaf virus (BOLV), and Beet virus $Q$ (BVQ), which are often found in mixed infections $(13,25,26,29,34)$, have not been elucidated. There is some evidence for antagonistic effects between BNYVV and BSBV from the studies of Prillwitz and Schlösser (34), and between BNYVV and BSBMV from the work of Mahmood and Rush (28) and Wisler et al. (47). Owing to the lack of an effective method to introduce different BNYVV isolates into a virus-free $P$. betae population, Koenig et al. (18) have used high inoculum doses of ground leaf tissue from Chenopodium quinoa lesions infected with BNYVV to inoculate young seedlings mechanically.

In this study, we cultivated sugar beet plants, whose roots had been inoculated mechanically, in soil infested with virus-free $P$. betae to load the vector with BNYVV isolates of varying aggressiveness. The different soil samples were used in resistance tests under controlled greenhouse conditions to investigate whether the ability to overcome resistance, which was observed in the field, was independent of the vector population and other soilborne factors.

\section{MATERIALS AND METHODS}

Preparation of viral isolates and inoculum. The BNYVV non-resistance-breaking A type isolate (referred to as A) was derived from Rovigo, Italy. The resistance-breaking $\mathrm{P}$ type isolate (referred to as P) was obtained from a soil sample collected in the Pithiviers region, France. Soils infested with A and P, respectively, were kindly supplied by KWS Saat AG (Einbeck, Germany). The resistance-breaking A type isolate from Imperial Valley, California, United States (referred to as IV) was kindly provided by B.-L. Lennefors (Syngenta Seeds AB, Landskrona, Sweden). Plants of the BNYVV-susceptible sugar beet cultivar ( $r z 1 r z 1$, described below) were grown as bait plants in infected soil, and root samples from the infected plants were used to inoculate the leaves of 5-week-old plants of the local lesion host $C$. quinoa. For the inoculation, small samples of root from plants infected with the different $\mathrm{BNYVV}$ isolates were diluted fivefold with $0.05 \mathrm{M}$ phosphate buffer $\left(1 \mathrm{~g}\right.$ of $\mathrm{KHPO}_{4}$ and $7.2 \mathrm{~g}$ of $\mathrm{Na}_{2} \mathrm{HPO}_{4}$ in 1 liter of DEPC-treated water, $\mathrm{pH} 7$ to 7.4). The leaves were inoculated using a cotton swab with Celite (Roth, Karlsruhe, Germany) as an abrasive. After two passages in C. quinoa, lesions were harvested at 10 days postinoculation and stored at $-80^{\circ} \mathrm{C}$ until inoculation.

Virus-free field soil that contained $P$. betae. A sample of field soil that contained $P$. betae but not BNYVV nor other soilborne sugar beet-infecting viruses, such as BSBV and BVQ, was collected from a sugar beet field in Reutershof, Brandenburg, Germany. In this particular field, sugar beet is grown in a 3-year rotation, but to date, no rhizomania has been reported. Initially, to confirm the presence of $P$. betae and absence of BNYVV, a 5 -week bait test comprised of 10 pots with seven plants each was carried out using an rzlrzl cultivar. The absence of BNYVV, BSBV, and BVQ was assessed by specific enzyme-linked immunosorbent assay (ELISA) (BNYVV) and by reverse transcription-polymerase chain reaction (RT-PCR) (BSBV, BVQ) using virus-specific primers (described below). The presence of $P$. betae in small rootlets was observed using a microscope.

Sugar beet genotypes. Three different sugar beet genotypes were used: one $R z l$-resistant cultivar $(R z \operatorname{lr} z 1)$, one $R z 1+R z 2$ cultivar, which carried the two major resistance genes $R z 1$ and $R z 2(R z 1 r z 1+R z 2 r z 2)$, and a susceptible cultivar ( $r z 1 r z 1)$. To allow direct comparison with results from different studies, we used previously reported genotypes $(18,27,32,33)$.

Vortex inoculation and cultivation. Sugar beet seedlings from a susceptible cultivar (described below) were inoculated mechanically in accordance with the method described by Koenig and
Stein (20), with some modifications. To inoculate 12-day-old seedlings, $4 \mathrm{ml}$ of inoculum of each BNYVV isolate (A, IV, and $\mathrm{P}$ ) and $40 \mathrm{mg}$ of carborundum (Sigma Aldrich Chemie $\mathrm{GmbH}$, Munich, Germany) were placed, together with the seedlings, in a $10-\mathrm{ml}$ plastic tube. The inoculum was prepared as described above. The tube was vortexed with a Vortex Genie 2 (Scientific Industries, Bohemia, NY; speed setting 6) for $30 \mathrm{~s}$, left for $30 \mathrm{~s}$, vortexed again for $30 \mathrm{~s}$, and then the plants were left for an additional $5 \mathrm{~min}$ in the suspension of inoculum. For the mockinoculated control, ground leaf tissue from healthy $C$. quinoa leaves was used in place of the inoculum. Seedlings were washed in tap water and planted in sterile soil that had been mixed 1:2 (vol/vol) with vermiculite (Vermiculite Dämmstoffe, Sprockhövel, Germany). The plants were kept in a greenhouse at $20^{\circ} \mathrm{C}$ without additional light for the next 2 days. Subsequently, the temperature was raised by $2^{\circ} \mathrm{C}$ every second day up to $24^{\circ} \mathrm{C}$ (day) $/ 18^{\circ} \mathrm{C}$ (night), and a 10-h photoperiod of additional light was introduced. For each viral isolate and the healthy control, 175 plants were inoculated mechanically and planted into pots $(25 \times 700 \mathrm{ml})$ per viral isolate (seven plants per pot) and randomized in a complete block design. The plants were cultivated for 5 weeks to allow multiplication of the virus before they were transplanted into field soil that contained the vector (described above), using the same number of pots per isolate and same design. Before transplantation, a representative root sample was removed from each pot and subjected to ELISA to determine the infection rate and BNYVV content. Subsequently, after a further 5 weeks of cultivation to allow the $P$. betae population to acquire the viral isolate (which we term viral loading), the plants were harvested. The concentration of BNYVV was determined by ELISA and infection with $P$. betae was verified microscopically. All the small roots of the plants were left in the respective soil samples, which were subsequently air-dried and mixed.

Resistance test. Soil samples in which $P$. betae had been loaded with one of the three different BNYVV isolates were used for a sugar beet resistance test with the three genotypes of sugar beet in 42 repetitions. For this test, $150 \mathrm{ml}$ pots were used. To control Aphanomyces cochlioides, the planted seedlings were treated with the fungicide Tachigaren 70 WP (Sumitomo, Düsseldorf, Germany) at $90 \mathrm{~g}$ per 100,000 plants. A total of 504 test pots were randomized in blocks that contained six pots each. After being grown for 10 weeks under the same conditions as described above, the plants were harvested and the small roots were used for RNA extraction and BNYVV ELISA.

Detection of BNYVV, BSBV, and BVQ. Small roots from beets that had been harvested from a single pot and pooled were processed immediately or stored at $-80^{\circ} \mathrm{C}$ until further processing. Ground root tissue was produced and BNYVV was detected and quantified as described previously (33). Root samples were considered to be infected with BNYVV when ELISA values exceeded the mean plus three times standard deviations of the healthy controls. For the detection and sequencing of BNYVV, BSBV, and BVQ, total RNA was extracted from samples of small roots (100 mg) using an RNeasy Plant Mini Kit (Qiagen, Hilden, Germany), in accordance with the manufacturer's protocol. RT-PCR conditions were as described previously $(22,33)$. For the detection and subsequent sequencing of the P25 ORF, primers BN333-low (5'-GTCCCAACCAGATCAACAA-3') and BN34-up (5'-TCGGAATATCCAAGGTTTAAAAG-3'), which amplified nucleotides 302 to 1207 of BNYVV RNA 3 (GenBank accession number M36894), were used. The presence of BNYVV RNA 5 was detected with primers that amplified the entire P26 ORF (nucleotides 447 to 1103 of GenBank accession number U78293). The presence of BSBV and BVQ was assayed by single RT-PCRs using the primers described by Meunier et al. (29). PCR products were visualized on a UV transilluminator after electrophoresis in a $1 \%$ agarose gel that contained ethidium bromide. The PCR products were purified using SureClean reagent (Bio- 
line Ltd., London, UK) and then sequenced by a commercial company (MWG Eurofins Operon, Ebersberg, Germany) with specific primers. The sequences were analyzed using the Vector NTI (Invitrogen, Karlsruhe, Germany) and Chromas Lite software packages (http://www.technelysium.com.au/chromas_lite.html).

Data analysis. Statistical analysis was carried out using SAS version 9.1 (SAS Institute, Cary, NC). The data regarding BNYVV content displayed a lack of homogeneity of variance; therefore, nonparametric analysis was performed to evaluate the data properly $(5,40)$. BNYVV content was assessed for mixed samples that consisted of four plants per pot. For each pot, the relative effect (RE) was calculated before an analysis of variance (ANOVA)-type statistical analysis was performed. The REs were used to perform a nonparametric test for factorial designs in accordance with Brunner and Munzel (5) and Shah and Madden (40). Least square means for the ranks of marginal effects with respect to virus content were computed to allow multiple comparisons between treatments (adjustment $=$ Tukey). To assign letters for multiple comparisons, we used the SAS macro MULT (https://www.uni-hohenheim.de/ bioinformatik/beratung/toolsmacros/sasmacros/mult.sas). For the REs of the single experimental units (one pot), estimated relative treatment effects with appropriate confidence limits were calculated with the SAS macro LD_CI (http://www.ams.med.unigoettingen.de/de/sof/ld/LD_CI.SAS). The data were evaluated as a series of randomized complete block designs with the factor block nested within location as a random effect. However, the randomization structure could not be implemented in the LD_CI macro. In addition to the less demonstrative RE, median values of the medians of the virus content of each pot and the extreme median values were calculated.

\section{RESULTS}

A virus-free $P$. betae population in soil can be loaded with different BNYVV isolates. To demonstrate that the ability of BNYVV isolates that carried four or five RNA species to overcome plant resistance was independent of the vector population, we attempted to load samples of field soil that contained the vector $P$. betae with the different isolates, BNYVV-A, -IV, and -P, from infected roots. Subsequently, the different soil samples were used for a greenhouse resistance test with different BNYVV-resistant cultivars of sugar beet. Small rootlets infected with BNYVV isolate $\mathrm{A}, \mathrm{IV}$, or $\mathrm{P}$ were used for mechanical inoculation of $C$. quinoa leaves. The absence of BVQ and BSBV in the inoculum was verified by RT-PCR. The amino acid sequence of P25, including the tetrad aa 67 to 70 , was determined for all isolates by direct sequencing of RT-PCR products generated from total RNA extracted from roots, followed by in silico translation. The following tetrad sequences were detected: IV, VLHG; P, SYHG; and A, ACHG (which all agreed with the previously published sequences). Leaf material from the second passage in C. quinoa was used to inoculate 175 sugar beet seedlings per isolate (susceptible cultivar, 25 pots with seven plants each) by the vortex method, after which the seedlings were cultivated in heatsterilized virus-free soil. For the negative control, plantlets were mock-inoculated with ground leaf tissue from healthy $C$. quinoa plants. From 9 to 12 days after mechanical vortex inoculation, several seedlings displayed symptoms of BNYVV infection on their leaves. These yellow lesions and veins occurred more frequently in plants inoculated with BNYVV P type than with the other two types (data not shown). Before transplantation into the vector-containing field soil, a lateral root sample from each of the 25 pots per isolate was checked for successful BNYVV infection by means of quantitative ELISA (mean virus content: A type, $79.3 \mathrm{ng} / \mathrm{ml}$; IV type, $108.8 \mathrm{ng} / \mathrm{ml}$; and $\mathrm{P}$ type, $71.8 \mathrm{ng} / \mathrm{ml}$ ). BNYVV infection was detected in nearly all plants (84 to $96 \%$; Table 1). After a further 5 weeks of cultivation in field soil that contained the vector, detection of the virus in the inoculum plants was repeated and BNYVV infection confirmed (mean virus content: A type, $90.3 \mathrm{ng} / \mathrm{ml}$; IV, $66.2 \mathrm{ng} / \mathrm{ml}$; and P, $52.3 \mathrm{ng} / \mathrm{ml})$. The percentage of plants that showed BNYVV infection was 8 to $20 \%$ lower than after mechanical inoculation. After the inoculum plants had been removed and the soil dried, resistance tests using the $r z 1 r z 1, R z 1 r z 1$, and $R z 1 r z 1+R z 2 r z 2$ cultivars were set up with the virus-infected soil samples. The total amount of soil differed between treatments because some soil was lost when the inoculum plants, which were the source of the virus, were harvested. This resulted in variable numbers of replications per plant genotype $\times$ isolate (Table 2). The number of replications varied between 38 and 48 pots, which contained four plants each. This very high number of replications and a total of four plants per replicate were chosen because: (i) natural vector-mediated infection with BNYVV is known to be highly variable; and (ii) commercial sugar beet cultivars do not display homogenous BNYVV infection. The plants were harvested after 10 weeks of cultivation in a greenhouse. No obvious phenotypic differences were found between treatments. Total RNA was prepared from small rootlets to verify the identity of the viral isolate and to detect possible cross contamination. The presence of the P25 and P26 ORFs was verified for all isolates by RT-PCR. P26 was only detected in plants infected with the P type virus. Direct sequencing of the PCR products for the P25 ORF and evaluation of electropherograms confirmed that all isolates showed the expected tetrad sequence, and the absence of double peaks showed that no mixed infections had occurred (data not shown). A lateral root sample was taken from all plants in each pot and used for the quantification of BNYVV by ELISA. The percentages of infected plants are shown in Table 1 . The high proportion of susceptible plants that tested positive for BNYVV infection (92.1 to 100\%) showed that loading of $P$. betae was successful and independent of the viral isolate. The proportion of virus-infected plants was lower in the $R z 1$ plants than in the susceptible plants. Among the $R z 1$

TABLE 1. Number of infected plants after vortex inoculation, Polymyxa betae loading, and the resistance test

\begin{tabular}{|c|c|c|c|c|}
\hline & & Vortex inoculation & Loading & Resistance test \\
\hline BNYVV isolate & Genotype & $\%$ Infected plants ${ }^{\mathrm{a}}$ & $\%$ Infected plants ${ }^{\mathrm{a}}$ & $\%$ Infected plants ${ }^{b}$ \\
\hline A & $r z 1 r z 1$ & 96 & 88 & 100.0 \\
\hline A & RzIrzl & $\mathrm{na}^{\mathrm{c}}$ & na & 45.0 \\
\hline A & $R z 1 r z 1+R z 2 r z 2$ & na & na & 4.5 \\
\hline IV & $r z 1 r z 1$ & 96 & 84 & 100.0 \\
\hline IV & $R z 1 r z 1$ & na & na & 87.5 \\
\hline IV & $R z 1 r z 1+R z 2 r z 2$ & na & na & 2.2 \\
\hline $\mathrm{P}$ & $r z 1 r z 1$ & 84 & 64 & 92.1 \\
\hline $\mathrm{P}$ & $R z 1 r z 1$ & na & na & 73.7 \\
\hline $\mathrm{P}$ & $R z 1 r z 1+R z 2 r z 2$ & na & na & 7.5 \\
\hline
\end{tabular}

a Mixed sample obtained from seven plants per pot.

${ }^{b}$ Mixed sample obtained from four plants per pot.

${ }^{\mathrm{c}}$ na $=$ not applicable. 
plants, the proportion was much higher in those grown in soil that contained type IV $(87.5 \%)$ or $\mathrm{P}(73.7 \%)$ than in soil that contained type A (45\%). Not surprisingly, in $R z 1+R z 2$ plants, only a few isolates displayed ELISA values that were above the limit. The obvious difference in the number of infected $R z l$ plants between the reference A type isolate and isolate IV, as well as the $P$ type, was consistent with the expected ability of the latter isolates to overcome resistance.

BNYVV isolates $I V$ and $P$ retain their ability to overcome $R z 1$ resistance when loaded into the same vector population. The mean ELISA absorption values for BNYVV in the lateral roots of $r z 1 r z 1$ (susceptible), $R z 1 r z 1$ (resistant), and $R z 1 r z 1+R z 2 r z 2$ (double-resistant) plants are shown in Table 2. Although all isolates gave a mean $A_{405}$ of 0.9 to 1.2 in $r z 1 r z 1$ plants, independent of their ability to overcome resistance, only the IV and $\mathrm{P}$ type isolates gave elevated levels of absorption in RzIrzl-resistant plants. In the $R z 1 r z 1+R z 2 r z 2$ plants, none of the isolates was able to produce ELISA values that were higher than those of the healthy controls. However, the nonhomogeneous distribution of virus in the lateral roots led to a relatively high mean SD. To evaluate the ability of the BNYVV isolates to produce an elevated concentration of virus in resistant plants, the ELISA readings displayed in Table 2 were used to calculate virus content, as represented by nanograms coat protein per milliliter ground root tissue. Representative values for the variation in virus content, minimum, median, and maximum of medians were calculated (Table 2). No BNYVV infection was detected in the roots of the healthy controls for any of the sugar beet genotypes. The highest concentrations of virus were detected in the small rootlets of susceptible ( $r z 1)$ plants. Remarkably, BNYVV IV and P types produced median virus contents that were only $25 \%$ of the median content produced by the A type. The variation in virus content was highest in plants infected with the $\mathrm{P}$ type isolate (4.8 to $248.8 \mathrm{ng} / \mathrm{ml}$ ground root tissue) and lowest in plants infected with the A type (284.9 to $515.7 \mathrm{ng} / \mathrm{ml}$ ). In $R z 1$ plants, contrasting virus contents were observed. The median virus contents produced by the IV and P type isolates were 10 to 20 times higher than those in the plants infected with the A type reference isolate. In contrast to the A type-infected $R z 1$ plants, the virus content of the plants infected with the BNYVV IV and P type isolates showed much greater variation, with maximum values (91.0 and $168.2 \mathrm{ng} / \mathrm{ml}$, respectively) that almost reached those obtained for both isolates in susceptible plants $(121.2$ and $107.7 \mathrm{ng} / \mathrm{ml}$, respectively). In addition to the very low percentage of infected $R z 1+R z 2$ plants that reached the ELISA threshold (Table 1), rootlets of the $R z 1+R z 2$ plants displayed very low ELISA values, which meant that no BNYVV could be detected, independent of the isolate.

To confirm the observed variation in virus content depending on the plant genotype and BNYVV isolate, the data were subjected to statistical analysis. ANOVA-type statistical analysis was performed and showed that viral isolate, plant genotype, and viral isolate $\times$ plant genotype had a significant effect $(* * * P<0.001)$ on the concentration of the virus in small rootlets (data not shown). To obtain the source of the effects for twofold interaction, the effects were sliced for sugar beet genotype and viral isolate, and are shown in Table 3. When the viral isolate was kept constant, the three different sugar beet genotypes, significantly affected the virus content, except in the healthy control. When the genotype was kept constant, a significant influence of the viral isolate on virus content was observed for the $R z l$ as well as the $r z l$ plants but not for the double-resistant $R z 1+R z 2$ cultivar.

As a result of the lack of homogeneity of variance, median values for the virus contents were used to calculate the REs shown in Figure 1. The REs for virus content that were induced by different isolates did not differ significantly in plants of the $R z 1+R z 2$ cultivar, and were indistinguishable from those of the healthy controls. In $R z 1$-resistant plants, REs that were induced

TABLE 2. Mean Beet necrotic yellow vein virus (BNYVV) enzyme-linked immunosorbent assay absorption values measured in the small rootlets of sugar beet genotypes grown in the resistance test, and measured total virus content for all replications per treatment

\begin{tabular}{|c|c|c|c|c|c|c|c|}
\hline \multirow[b]{2}{*}{ BNYVV type ${ }^{a}$} & \multirow[b]{2}{*}{ Genotype } & \multirow[b]{2}{*}{ Mean $\mathrm{A}_{405}$} & \multirow[b]{2}{*}{$\mathrm{MSD}^{\mathrm{b}}$} & \multirow[b]{2}{*}{$\begin{array}{l}\text { Number of } \\
\text { replications }\end{array}$} & \multicolumn{3}{|c|}{ Virus content $^{\mathrm{c}}$} \\
\hline & & & & & $\begin{array}{l}\text { Maximum of } \\
\text { medians }\end{array}$ & $\begin{array}{l}\text { Median of } \\
\text { medians }\end{array}$ & $\begin{array}{c}\text { Minimum of } \\
\text { medians }\end{array}$ \\
\hline hc & $R z 1 r z 1+R z 2 r z 2$ & 0.121 & 0.01 & 40 & 0 & 0 & 0 \\
\hline $\mathrm{P}$ & $R z 1 r z 1+R z 2 r z 2$ & 0.140 & 0.07 & 40 & 0 & 0 & 0 \\
\hline IV & $R z 1 r z 1+R z 2 r z 2$ & 0.129 & 0.08 & 46 & 0 & 0 & 0 \\
\hline A & $R z 1 r z 1+R z 2 r z 2$ & 0.135 & 0.07 & 44 & 0 & 0 & 0 \\
\hline hc & $R z 1 r z 1$ & 0.114 & 0.01 & 39 & 0 & 0 & 0 \\
\hline $\mathrm{P}$ & $R z 1 r z 1$ & 0.617 & 0.59 & 38 & 168.240 & 8.373 & 0 \\
\hline IV & $R z 1 r z 1$ & 0.583 & 0.42 & 40 & 91.060 & 20.313 & 9.350 \\
\hline A & $R z 1 r z 1$ & 0.277 & 0.25 & 42 & 23.000 & 0.825 & 0 \\
\hline hc & $r z 1 r z 1$ & 0.166 & 0.02 & 38 & 0 & 0 & 0 \\
\hline $\mathrm{P}$ & $r z 1 r z 1$ & 0.949 & 0.63 & 38 & 248.889 & 107.742 & 4.876 \\
\hline IV & $r z 1 r z 1$ & 1.040 & 0.41 & 48 & 227.200 & 121.216 & 88.579 \\
\hline A & $r z 1 r z 1$ & 1.261 & 0.22 & 42 & 515.753 & 441.223 & 284.995 \\
\hline
\end{tabular}

${ }^{\mathrm{a}}$ hc $=$ healthy control.

${ }^{\mathrm{b}} \mathrm{MSD}=$ mean standard deviation of absorption.

c Absolute virus content in small rootlets in nanograms per milliliter of ground root tissue.

TABLE 3. Analysis of variance-type statistical analysis for Beet necrotic yellow vein virus content in small rootlets of sugar beet plants grown in the resistance test (test of effect slices) $^{\mathrm{a}}$

\begin{tabular}{|c|c|c|c|c|c|c|}
\hline Effect & VI & Genotype & NomDF & DenDF & $F$ \value & $P>\mathrm{F}$ \\
\hline $\mathrm{VI} \times \mathrm{SB}$ & Healthy & $\ldots$ & 2 & 68 & 0.00 & $1.0000 \mathrm{~ns}$ \\
\hline $\mathrm{VI} \times \mathrm{SB}$ & A & $\ldots$ & 2 & 68 & 136.35 & $<0.0001 * * *$ \\
\hline $\mathrm{VI} \times \mathrm{SB}$ & IV & $\ldots$ & 2 & 68 & 129.00 & $<0.0001 * * *$ \\
\hline $\mathrm{VI} \times \mathrm{SB}$ & $\ldots$ & $r z 1 r z 1$ & 3 & 68 & 131.01 & $<0.0001 * * *$ \\
\hline $\mathrm{VI} \times \mathrm{SB}$ & $\ldots$ & $R z 1 r z 1$ & 3 & 68 & 57.57 & $<0.0001 * * *$ \\
\hline $\mathrm{VI} \times \mathrm{SB}$ & $\ldots$ & $R z 1 r z 1+R z 2 r z 2$ & 3 & 68 & 2.48 & $0.0688 \mathrm{~ns}$ \\
\hline
\end{tabular}

a VI, virus isolate; SB, sugar beet; NomDF, nominator degrees of freedom; DenDF, denominator degrees of freedom. Levels of significance: $* * *$ indicates $P<$ 0.001 ; ns $=$ not significant. 
by the A type isolate were significantly lower (three levels of significance) than those in susceptible plants. In contrast, these $R E$ values were not significantly different from each other when $P$ type infections in $R z l$ versus $r z l$ cultivars were evaluated, and differed by one level of significance in the case of the IV isolate. Although the virus content in susceptible plants differed by a factor of four between the reference and resistance-breaking isolates, the high variability of the absolute virus contents prevented the detection of significant differences, except between the $\mathrm{P}$ and A types. Although the absolute BNYVV contents in susceptible rzl plants were approximately four times higher in the A type infected than in the IV and P type-infected plants (Table 2), these differences were only statistically significant between REs that were induced by the A type and P type isolates, respectively (Fig. 1). Similar relationships were observed when the REs of viral isolates were compared in $R z l$ plants. Only the IV type induced significantly higher virus contents in $R z 1$-resistant plants than BNYVV A type.

\section{DISCUSSION}

Our experiments resulted in two major findings that both support the initial working hypothesis that differences in aggressiveness between BNYVV isolates are independent of the vector population, but might be influenced in the field by other biotic and abiotic soil factors.

First, we showed that a natural soilborne virus-free population of $P$. betae could be loaded with BNYVV in field soil with high efficiency by the culture of sugar beet seedlings that had been inoculated mechanically with BNYVV. When the viral inoculum obtained from $C$. quinoa lesions was of high quality (high density of lesions and little or no leaf damage), the method resulted in high infection rates for all three isolates and the subsequent production of large amounts of infected soil. This allowed us to set up a resistance test with a sufficient number of replicates to differentiate among viral isolates that showed different degrees of aggressiveness in the field. Previous studies of the functions of viral proteins involved in vector transmission have used non- viruliferous zoospore suspensions from systemically infected Beta macrocarpa plants for virus acquisition and viruliferous zoospores for transmission $(42,43)$. To the best of our knowledge, there has only been one previous study that has shown that a virus-free $P$. betae population can acquire BNYVV from leafinoculated, systemically infected Spinacia oleracea, and transmit it through the soil to neighboring sugar beet roots (22). However, the authors of the earlier study did not separate the root systems of the virus donor and bait plants entirely. In addition to the application used in this study, the ability to load a virus-free population of $P$. betae might enable investigation of the proposed interaction of BNYVV with BSBV or BSBMV, or the establishment of standardized resistance tests with other plasmodiophoridtransmitted viruses $(3,21)$.

Second, in this study, we aimed to demonstrate that BNYVV isolates that caused a reduction in yield in $R z l$ sugar beets in the field and produced elevated concentrations of virus in lateral roots in greenhouse tests retained their increased aggressiveness when loaded into the same vector population in field soil. To evaluate rhizomania resistance in sugar beet, and demonstrate the ability to overcome resistance, remains a challenge, because resistance is expressed as a quantitative trait, with a phenotype of reduced replication and movement of the virus as well as a lower reduction in yield. In practice, yield produced in infected soil is the main criterion for the registration of cultivars. Several previous studies have shown that virus content in small rootlets is a measure of resistance and correlates with yield performance during natural BNYVV infestation in the field $(6,7,10,11)$.

The elevated concentration of BNYVV $\mathrm{P}$ type in $R z 1$ plants was in accordance with the findings of previous field and greenhouse studies $(32,33)$, except that in the current study the P type did not lead to detectable concentrations of virus in the doubleresistant cultivar. This indicates that other environmental factors interfered with the expression of resistance. The BNYVV IV isolate, which is able to produce strong BNYVV symptoms and reduce the yield in $R z l$ cultivars, retains the ability to overcome $R z 1$ resistance $(27,33)$ when loaded into an independent virus-free population of $P$. betae. Future resistance studies should use

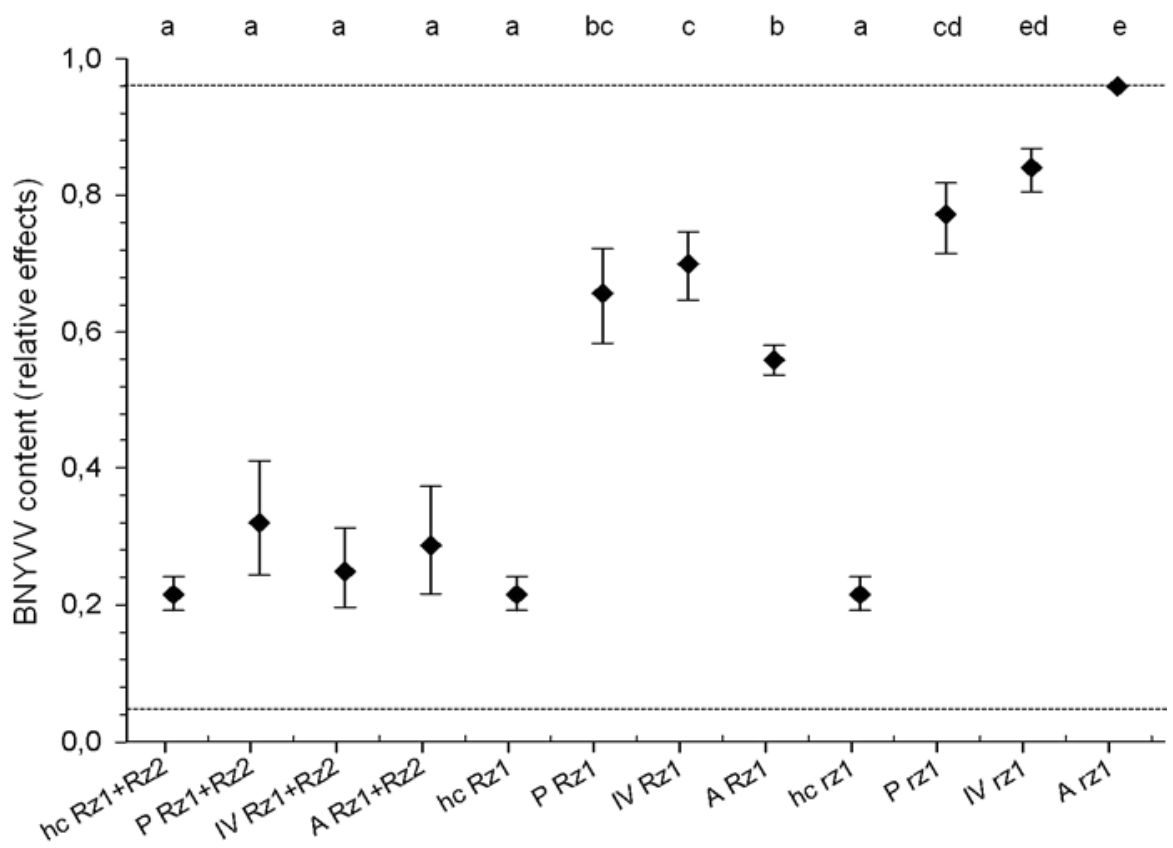

Fig. 1. Total virus contents induced by three Beet necrotic yellow vein virus (BNYVV) isolates in different sugar beet genotypes shown as the range of relative effects; greenhouse resistance test with 10-week-old plants. $y$ axis: BNYVV content expressed as relative effects of replication per variant. $x$ axis: A, BNYVV A type; IV, BNYVV IV type; P, BNYVV P type; hc, healthy control $\times$ sugar beet genotypes: $R z 1+R z 2, R z 1 R z 2$ double-resistant genotype; $R z 1 r z 1, R z 1$ singleresistant genotype; and $r z 1 r z 1$, susceptible genotype. Whiskers: $95 \%$ confidence interval. For relative effects with nonoverlapping letters, ranges differ significantly ( $\alpha=0.05$, adjustment: Tukey). The upper and lower limits of the relative effects are displayed as dotted lines. 
additional $P$. betae isolates from different geographic origins to establish whether variations exist in their ability to act as a vector.

The comparison of infection efficiency for all three isolates and plant genotypes (Table 1) illustrated convincingly that quantitative resistance reduced viral replication and the number of plants that showed a virus content above the threshold of the quantitative ELISA. In the incompatible interaction between $R z 1$ and the A type isolate, only half of the plants were rated as infected. In contrast, when $R z l$ plants were exposed to either of the two resistance-breaking isolates, viral replication and infection efficiency were both increased significantly, and nearly reached the levels observed in susceptible plants. The additive effects of the two major resistance genes reduced the infection efficiency further in a dramatic manner, as suggested by Gidner et al. (9). When the absolute virus contents in the $r z, 1$ susceptible plants are compared, it might be assumed that the A type strain possesses enhanced fitness in comparison to the IV and P types, although only the values for the $\mathrm{P}$ type were significantly lower. It is possible that $\mathrm{P} 25$, which is encoded by RNA 3, interferes directly or indirectly with factors encoded by $R z 1$, which allow the virus to infect more efficiently and replicate to a higher level, and that this in turn interferes negatively with propagation (rather than infection efficiency) in susceptible host plants, which leads to reduced fitness. This observation of possible variation in fitness complicates the evaluation of absolute virus contents in $R z l$ plants in this study, and the confirmation of resistance-breaking ability, when the three isolates are compared. The $\mathrm{P}$ type virus content, which was indistinguishable between the susceptible and $R z l$ plants, clearly indicates that resistance has been overcome. In the case of BNYVV IV, the ability to overcome resistance in $R z l$ plants can be deduced from the different levels of significance by which the virus content differed when compared with the reference A type isolate. The content of BNYVV A differed between $R z l$ and $r z 1$ plants by three levels of significance, whereas only one level of difference was detected for BNYVV IV. The resistance assay performed in this study, which used natural vector-driven infection and a standardized population of vector, shows that transmission by the vector adds another source of variability to virus content that depends on plant genotype. This becomes clear when the data are compared with those obtained by mechanical inoculation (18).

\section{ACKNOWLEDGMENTS}

We thank A. Walter and H. Korf for their excellent technical assistance; U. Beiersdorf for providing us with rhizomania-free soil; C. Buhre for helpful comments and critical discussions; C. Kluth for statistical advice; and R. Berglas and D. McIntosh for critical reading of the manuscript.

\section{LITERATURE CITED}

1. Acosta-Leal, R., Bryan, K. B., Smith, J. T., and Rush, C. M. 2010. Breakdown of host resistance by independent evolutionary lineages of Beet necrotic yellow vein virus involves a parallel C/U mutation in its p25 gene. Phytopathology 100:127-133.

2. Acosta-Leal, R., Fawley, M. W., and Rush, C. M. 2008. Changes in the intraisolate genetic structure of Beet necrotic yellow vein virus populations associated with plant resistance breakdown. Virology 376:60-68.

3. Adams, M. J., Swaby, A. G., and Macfarlane, I. 1986. The susceptibility of barley cultivars to Barley yellow mosaic virus (BaYMV) and its fungal vector, Polymyxa graminis. Ann. Appl. Biol. 109:561-572.

4. Biancardi, E., Lewellen, R. T., de Biaggi, M., Erichsen, A. W., and Stevanato, P. 2002. The origin of rhizomania resistance in sugar beet. Euphytica 127:383-397.

5. Brunner, E., and Munzel, U. 2002. Nichtparametrische Datenanalysen. Springer, Berlin.

6. Bürcky, K., and Büttner, G. 1985. Ansätze zur Selektion rizomaniatoleranter Zuckerrüben während der Jugendentwicklung-I. Virustiter. Zuckerindustrie 110:997-1000.

7. Bürcky, K., and Büttner, G. 1991. Gehalt an Beet necrotic yellow vein virus (BNYVV) in der Hauptwurzel von Zuckerrübenpflanzen verschiedener Sorten und deren Leistung unter Rizomaniabefall im Feld. J. Phytopathol. 131:1-10.

8. Dunoyer, P., Pfeffer, S., Fritsch, C., Hemmer O., Voinnet, O., and Richards, K. E. 2002. Identification, subcellular localization and some properties of a cysteine-rich suppressor of gene silencing encoded by peanut clump virus. Plant J. 29:555-567.

9. Gidner, S., Lennefors, B.-L., Nilsson, N.-O., Bensefelt, J., Johansson, E., Gyllenspetz, U., and Kraft, T. 2005. QTL mapping of BNYVV resistance from the WB41 source in sugar beet. Genome 48:279-285.

10. Giunchedi, L., de Biaggi, M., and Poggi Pollini, C. 1985. Evaluation of ELISA technique for the screening of Rhizomania-tolerant sugar beet genotypes. Pages 385-390 in: Proceedings of the 48th Congress of the IIRB (International Institute for Beet Research), IIRB, Brussels.

11. Giunchedi, L., de Biaggi, M., and Pollini, C. 1987. Correlation between tolerance and Beet necrotic yellow vein virus in sugar beet genotypes. Phytopathol. Mediter. 26:23-28.

12. Harju, V. A., Mumford, R. A., Blockley, A., Boonham, N., Clover, G. R. G., Weekes, R., and Henry, C. M. 2002. Occurrence in the United Kingdom of Beet necrotic yellow vein virus isolates which contain RNA5. Plant Pathol. 51:811.

13. Heidel, G. B., and Rush, C. M. 1994. Distribution of beet necrotic yellow vein virus, beet distortion mosaic virus, and an unnamed soilborne sugar beet virus in Texas and New Mexico. Plant Dis. 78:603-606.

14. Heijbroek, W., Musters, P. M. S., and Schoone, A. H. L. 1999. Variation in pathogenicity and multiplication of Beet necrotic yellow vein virus (BNYVV) in relation to the resistance of sugar beet cultivars. Eur. J. Plant Pathol. 105:397-405.

15. Johansson, E. 1985. Rhizomania in sugar beet-A threat to beet growing that can be overcome by plant breeding. Sveriges Utsädesförenings Tidskrift 95:115-121.

16. Koenig, R., Jarausch, W., Li, Y., Commandeur, U., Burgermeister, W., Gehrke, M., and Lüddeke, P. 1991. Effect of recombinant Beet necrotic yellow vein virus with different RNA compositions on mechanically inoculated sugarbeets. J. Gen. Virol. 72:2243-2246.

17. Koenig, R., Kastirr, U., Holtschulte B., Deml, G., and Varrelmann, M. 2008. Distribution of various types and P25 subtypes of Beet necrotic yellow vein virus in Germany and other European countries. Arch. Virol. 153:2139-2144.

18. Koenig, R., Loss, S., Specht, J., Varrelmann, M., Lüddecke, P., and Deml, G. 2009. A single U/C nucleotide substitution changing alanine to valine in the Beet necrotic yellow vein virus P25 protein promotes increased virus accumulation in roots of mechanically inoculated, partially resistant sugar beet seedlings. J. Gen. Virol. 90:759-763.

19. Koenig, R., Lüddecke, P., and Haeberlé, A. M. 1995. Genome difference between beet necrotic yellow vein virus (BNYVV) sources from different parts of the world. Pages 271-278 in: Proceedings of the 58th Congress of the IIRB (International Institute for Beet Research), IIRB, Brussels

20. Koenig, R., and Stein, B. 1990. Distribution of Beet necrotic yellow vein virus in mechanically inoculated sugarbeet plantlets of cultivars with different degrees of rhizomania resistance. Schriftenreihe der Deutschen Phytomedizinischen Gesellschaft, vol. 1. Pages 87-90 in: Proceedings of the First Symposium of the International Working Group on Plant Viruses with Fungal Vectors, IIRB, Brussels.

21. Kühne, T. 2009. Soil-borne viruses affecting cereals-Known for long but still a threat. Virus Res. 14:174-183.

22. Lemaire, O., Merdinoglu, D., Valentin, P., Putz, C., Ziegler-Graff, V., Guiney, H., Jonard, G., and Richards, K. 1988. Effect of Beet necrotic yellow vein virus RNA composition on transmission by Polymyxa betae. Virology 162:232-235.

23. Lewellen, R. T., Skoyen, I. O., and Erichsen, A. W. 1987. Breeding sugar beet for resistance to rhizomania: Evaluation of host-plant reactions and selection for and inheritance of resistance. Pages 139-156 in: Proceedings of the IIRB 50th Winter Congress (Vol. II), IIRB, Brussels.

24. Li, M., Liu, T., Wang, B., Han, C., Li, D., and Yu, J. 2008. Phylogenetic analysis of Beet necrotic yellow vein virus isolates from China. Virus Genes 36:429-433.

25. Liu, H. Y., and Lewellen, R. T. 2007. Distribution and molecular characterization of resistance-breaking isolates of Beet necrotic yellow vein virus in the United States. Plant Dis. 91:847-851.

26. Liu, H. Y., and Lewellen, R. T. 2008. Suppression of resistance-breaking Beet necrotic yellow vein virus isolates by Beet oak-leaf virus in sugar beets. Plant Dis. 92:1043-1047.

27. Liu, H. Y., Sears, J. L., and Lewellen, R. T. 2005. Occurrence of resistance-breaking Beet necrotic yellow vein virus of sugar beet. Plant Dis. 89:464-468.

28. Mahmood T., and Rush, C. 1999. Evidence of cross protection between Beet soilborne mosaic virus and Beet necrotic yellow vein virus in sugar beet. Plant Dis. 83:521-526. 
29. Meunier, A., Schmit, J. F., Stas, A., Kutluk, N., and Bragard, C. 2003. Multiplex reverse transcription-PCR for simultaneous detection of beet necrotic yellow vein virus, Beet soilborne virus, and Beet virus $Q$ and their vector Polymyxa betae KESKIN on sugar beet. Appl. Environ. Microbiol. 69:2356-2360.

30. Miyanishi, M., Kusume, T., Saito, M., and Tamada, T. 1999. Evidence for three groups of sequence variants of Beet necrotic yellow vein virus RNA 5. Arch. Virol. 144:879-892.

31. Peltier, C., Hleibieh, K., Thiel, H., Klein, E., Bragard, C., and Gilmer, D. 2008. Molecular biology of the Beet necrotic yellow vein virus. Plant Viruses 2:14-24.

32. Pferdmenges, F., Korf, H., and Varrelmann, M. 2009. Identification of rhizomania-infected soil in Europe able to overcome $R z l$ resistance in sugar beet and comparison with other resistance-breaking soils from different geographic origins. Eur. J. Plant Pathol. 124:31-43.

33. Pferdmenges, F., and Varrelmann, M. 2009. Breaking of Beet necrotic yellow vein virus resistance in sugar beet is independent of virus and vector inoculum densities. Eur. J. Plant Pathol. 124:231-245.

34. Prillwitz, H., and Schlösser, E. 1993. Interactions between Beet soilborne virus (BSBV-2) and Beet necrotic yellow vein virus (BNYVV). J. Plant Dis. Prot. 100:665-669.

35. Rahim, M. D., Andika, I. B., Han, C., Kondo, H., and Tamada, T. 2007. RNA 4-encoded p31 of Beet necrotic yellow vein virus is involved in efficient vector transmission, symptom severity and silencing suppression in roots. J. Gen. Virol. 88:1611-1619.

36. Rush, C. M., Liu, H.-Y., Lewellen, R. T., and Acosta-Leal, R. 2006. The continuing saga of rhizomania of sugar beets in the United States. Plant Dis. 90:4-15.

37. Schirmer, A., Link, D., Cognat, V., Moury, B., Beuve, M., Meunier, A., Bragard, C., Gilmer, D., and Lemaine, O. 2005. Phylogenetic analysis of isolates of Beet necrotic yellow vein virus collected worldwide. J. Gen. Virol. 86:2897-2911.

38. Scholten, O. E., De Bock, T., Klein-Lankhorst, R. M., and Lange, W. 1999. Inheritance of resistance to Beet necrotic yellow vein virus in Beta vulgaris conferred by a second gene for resistance. Theor. Appl. Gen. 99:740-746.

39. Scholten, O. E., Paul, D., van Lent, J. W. M., and Goldbach, R. W. 1994. In situ localization of beet necrotic yellow vein virus (BNYVV) in rootlets of susceptible and resistant beet plants. Arch. Virol. 136:349-361.

40. Shah, D. A., and Madden, L. V. 2004. Nonparametric analysis of ordinal data in designed factorial experiments. Phytopathology 94:33-43.

41. Tamada, T., Miyanishi, M., Kondo, H., Chiba, H., and Han, C. G. 2003. Pathogenicity and molecular variability of Beet necrotic yellow vein virus isolates from Europe, Japan, China and the United States. Pages 13-16 in: Proceedings of the Fifth Symposium of the International Working Group on Plant Viruses with Fungal Vectors. C. M. Rush, ed. American Society of Sugar Beet Technologists, Denver, CO

42. Tamada, T., Schmitt, C., Saito, M., Guilley, H., Richards, K., and Jonard, G. 1996. High resolution analysis of the readthrough domain of Beet necrotic yellow vein virus readthrough protein: A KTER motif is important for efficient transmission of the virus by Polymyxa betae. J. Gen. Virol. 77:1359-1367.

43. Tamada, T., Shirako, Y., Abe, H., Saito, M., Kiguchi, T., and Harada, T. 1989. Production and pathogenicity of isolates of beet necrotic yellow vein virus with different numbers of RNA components. J. Gen. Virol. 70:3399-3409.

44. Tamada, T., Uchino, H., Kusume, T., and Saito, M. 1999. RNA 3 deletion mutants of beet necrotic yellow vein virus do not cause rhizomania disease in sugar beets. Phytopathology 89:1000-1006.

45. Ward, L., Koenig, R., Budge, G., Garrido, C., McGrath, C., Stubbley, H., and Boonham, N. 2007. Occurrence of two different types of RNA-5-containing Beet necrotic yellow vein virus in the UK. Arch. Virol. 152:59-73.

46. Whitney, E. D. 1989. Identification, distribution, and testing for resistance to rhizomania in Beta maritima. Plant Dis. 73:287-290.

47. Wisler, G. C., Lewellen, R. T., Sears, J. L., Wasson, J. W., Liu, H. Y., and Wintermantel, W. M. 2003. Interactions between Beet necrotic yellow vein virus and Beet soilborne mosaic virus in sugar beet. Plant Dis. $87: 1170-1175$ 